\title{
The Life of a Text: Carsten Niebuhr and 'Abdal-Raḥmān Ag̀a's Das innere von Afrika
}

\author{
Camille Lefebvre
}

In July 1772, 'Abd al-Rahmmān Aġa, a Tripolitan ambassador, and his entourage including two African slaves arrived in Copenhagen to renegotiate peace with the Nordic states of Denmark and Sweden. Muslim missions were a common and fairly regular phenomenon of the 18TH century Mediterranean cross-cultural diplomacy.1 Cases of Ottoman, Persian, Moroccan or Maghreb envoys coming to Europe to negotiate conditions for the maintenance of peace against a payment for their ruler were not uncommon.2 But there is more than this to the story of 'Abd al-Rahmān Aga's four-month stay in Copenhagen. In the course of his trip, Abd al-Rahmān Aga met and befriended the last living member of the Danish expedition to Arabia, Carsten Niebuhr. The conversations between the scientist, the Tripolitan ambassador, and his two African slaves that summer were transformed twenty years later into a printed account comprising five texts, which constitute one of the rare sources about the Central Sahara and Sahel in the second half of the 18TH century.3

This paper is a story of connectivity, of circulation of information, and of the cross-cultural co-production of knowledge. Connectivity in the early

* I am indebted to a lot of people who helped me decipher this complex story and work with various languages and scripts. I would like to thank for their invaluable help Dan Andersen, Larry Baack, Guillaume Calafat, Clélia Coret, Michel-Pierre Detalle, Violette Diaz, Jean Charles Ducène, Torbjørn Ødegaard, Joachim Östlund, M'hamed Oualdi, Margarete Ritzkowsky, Enaam Sharfeddine, Robin Seignobos, Rafaël Thiebaut, Elena Vezzadini, Ismail Warscheid, and Toby Green and Benedetta Rossi for their advice in the process of revising this paper.

This research has received funding from the European Research Council (ERC) under the European Union's Horizon 2020 research and innovation programme, ERC-STG 2017 Grant agreement n 759390

1 Mathieu Grenet, "Muslim Missions to Early Modern Francec.1610-c.1780: Notes fora Social History of Cross-Cultural Diplomacy," Journal of Early Modern History 19 (2015): 7.

2 Nabil Matar, In the Lands of the Christians: Arabic Travel Writing in the Seventeenth Century (London: Routledge, 2003), 72-117; Lucette Valensi, Ces Étrangers familiers: Musulmans en Europe, XVIe-XVIIIe Siècles (Paris: Éd. Payot\&Rivages, 2012), 193-234.

3 Carsten Niebuhr, "Das InnerevonAfrika,"NeuesDeutschesMuseum(October 1790):963-1003; "Noch Etwas Über das Innere von Afrika," Neues Deutsches Museum (May 1791): 419-435; "Noch Etwas Über die Mohammedanischen Freistaaten in der Barbarei," Neues Deutsches Museum (January 1791): 1-26; "Noch Etwas Über die Mohammedanischen Freistaaten in der Barbarei. Fortsetzung," Neues Deutsches Museum (February 1791): 115-133; "Bemerkungen 
modern world is the subject of numerous studies of intellectual networks cutting across empires, cultures and religious boundaries, or of biographies of individuals whose life and travels spanned across continents. 4 The encounter between a North African ambassador deeply involved in cross-cultural trade between Istanbul, Europe and the central Sahara and Sahel, a Danish scientist who spentfiveyears as a lone traveller in the Arab world, and two Sub-Saharan African slaves closely acquainted with multiple cultures and languages, resulted in an intellectual and scientific exchange producing new knowledge about central west Africa.

Following PauloFernandode Moraes Farias, this paperdoes notseewritten sources as reservoirs of raw data, but rather it inquires into the political and social circumstances that led to the production of what we call our 'sources.'5 Thus this paper analyses the texts that resulted from the encounter of Niebuhr, 'Abd al-Rahmān, and his slaves in order to reveal these individuals' projects and the cultural rationales that underpinned them. The texts written and published by Carsten Niebuhr-especially Das Innere von Afrika and Noch etwas über die mohammedanischen Freistaaten in der Barbarei-are palimpsests of mixed oral and written cultures. They are informed by oral culture because Niebuhr's informants relied on news they received in Tripoli about Fezzan, Afnu (Hausa) and Bornu from merchants coming from, or living in, these regions, as well as on the memories of slaves abducted from their homeland as children. These texts relied, too, on several written cultures: the growing field of German orientalism, and also the emerging autonomous literature written in Tripoli by local scholars and intellectuals. This chapter thus aims to uncover how this exchange of information worked: what forms of communication occurred, and how interpersonal interactions, learned discussions, and intimate conversations resulted in reciprocal knowledge-creation and textual

überFr Hornemann's Reise nach denn Innern von Afrika," Monatlische Correspondenz (1803): 429-435.

4 Sebouh David Aslanian, From the Indian Ocean to the Mediterranean: The GlobalTrade Networks of Armenian Merchants from New Julfa (Berkeley: University of California Press, 2011); Mercedes García-Arenal, Gerard Wiegers, A Man of Three Worlds: Samuel Pallache, a Moroccan Jew in Catholic and Protestant Europe, (Baltimore: Johns Hopkins University Press, 2003); John-Paul Ghobrial, The Whispers of Cities: Information Flows in Istanbul, London, and Paris in the Age of William Trumbull (Oxford: Oxford University Press, 2013); Francesca Trivellato, The Familiarity of Strangers: The Sephardic Diaspora, Livorno, andCross-CulturalTrade in the Early Modern Period (New Haven: Yale University Press, 2009).

5 Paulo Fernando de Moraes Farias, Arabic Medieval Inscriptions from the Republic of Mali: Epigraphy, Chronicles, and Songhay-Tuāreg History (Oxford: Oxford University Press, 2003), LXIX-LXX. 
co-production. The chapter examines the protagonists' previous individual experiences and looks at how these experiences enabled them to understand each other and discuss common interests. Moraes Farias analysed how Barth's views on African history took shape by considering the material conditions of Barth's travels - what copies of manuscripts he had access to in Gwandu; how he was hosted in Timbuktu; who he was able (or unable) to talk to; how he moved; where he could or could not go; and what were his language skills. 6 Similarly, this chapter considers how communication occurred and information was exchanged in a particular African-European encounter.

What follows is necessarily an incomplete tale, because of the unbalanced nature of sources which consists, on the one hand, of abundant European diplomatic sources and, on the other hand, of almost inexistent data on African slaves. Carsten Niebuhr and 'Abd al-Rahmmān Aga's encounter happened at the intersection of several documentary traditions, including Mediterranean diplomatic correspondence, commercial record-keeping cultures, and multiple genres of scientific production from German orientalism to Tripolitan Arabic historical literature. Each tradition produced accounts in various languages (including Arabic, German, French, Italian, Lingua franca, and Danish) and various scripts such as Danish and German Fraktur and kurrentschrift (typographic script and hand-writing) or classical Arabic. Furthermore, some aspects of this encounter are forever lost to us because we cannot access directly the words of the two African slaves. There are no sources reporting verbatim 'Abd al-Rahmān Aga's words and the testimonies of his slaves, which are always mediated through the reports of others. But by reading Niebuhr's' texts against the grain and looking for explicit references to information provided by his African informants, we can identify the contributions of 'Abd al-Rahmān Aga and his slaves. We can thus attempt to interpret the political and intellectual projects of an African diplomat and his dependants travelling across the Mediterranean in the 1770 s.

A Diplomatic Context

In the eighteenth century, in order to trade safely in the Mediterranean Sea, to guarantee the control of piracy and the security of their ships, European

6 Moraes Farias, Arabic, XLVI-LI; Paulo Fernando de Moraes Farias, "Barth, Fondateur d'une Lecture Réductrice des Chroniques de Tombouctou," in Mamadou Diawara, Paulo Fernando de Moraes Farias, Gerd Spittler, eds., Heinrich Barth et l'Afrique (Cologne: R. Köppe, 2006), 215-224. 
states negotiated peace treaties with Maghrebi states.7 Diplomatic relations between European countries and the regencies of the Maghreb were organized by treaties, sealed and ratified by the two parties. This direct negotiation confirmed the relative autonomy of the regencies from Istanbul, even though Ottoman suzerainty was acknowledged in the treaties.8 But this new diplomatic sovereignty of the Maghrebi states was diminished by increasing military imbalance with the European states in the second half of the century. These treaties limited corsair operations in the co-signatory states, provided European merchants with trade outlets in the Maghreb; and supplied Maghreb regencies with cash, European products and trading opportunities with Europe. 9 It is in this context, that peace between Denmark and Tripoli had been signed in 1757, followed by a first Tripolitan embassy in the Nordic countries. Maghreb rulers sent embassies to Europe regularly for many different official reasons, such as the enforcement of bilateral peace treaties, signing of trade agreements, ransoming of captives or participation in various ceremonial events (coronation, baptism, etc.). 10

The idea of a new Tripolitan embassy in Denmark was first raised at the eve of the new regime in Copenhagen in 1770. In theory, from the 17th century onwards, the validity of treaties with European states was permanent and not anymore tied to the individual Monarch who signed the treaty in question. But in North Africa during 18TH century it was still current practice to consider the death of the beneficiary as putting an end to the validity of the treaty.11 In fact, in 18TH century Maghreb and Morocco, Islamic jurists saw diplomacy with non-Muslims as an approved instrument of policy as long as the agreements reached were temporary and short term. 12 In the European context,

7 Daniel Panzac, "Une Activité en Trompe-l'œil: La Guerre de Course à Tripoli de Barbarie dans la Seconde Moitié du XVIII Siècle," Revue de l'Occident Musulman et de la Méditerrané 47 (1988): 138.

8 Guillaume Calafat, "Ottoman NorthAfrica and iuspublicumeuropceum: The Case of the Treaties of Peace and Trade(1600-1750)," in Antonella Alimento, ed., War, Trade and Neutrality: Europe and the Mediterranean in the Seventeenth and Eighteenth Centuries (Milan: Angeli, 2011), 173.

9 Calafat, "Ottoman," 173; Enaam Sharfeddine, La Classe Marchande dans l'Iyalat Ottoman de Tarabulusal-Gharb (Tripoli) sousles Qaramanlis 1711-1835 (unpublished PhD diss., AixMarseille Université, 2012), 283.

10 Grenet, "Muslim Missions," 10; Christian Windler, La Diplomatie Comme Expérience de l'Autre: Consuls Français au Maghreb(1700-1840), (Genève: Droz, 2002), 239.

11 Windler, La Diplomatie, 221 and 241.

12 Susan Gilson Miller, Disorienting Encounters: Travels of a Moroccan Scholar in France in 1845-1846: The Voyage of Muhammad as-Saffār (Los Angeles: University of California Press, 1992), 11-12. 
these embassies were financed by European monarchies, which tried to avoid incurring excessive expenditures in connection to diplomatic missions. Official correspondence between the courts and their consular representatives in Mediterranean coastal countries reveal constant attempts to prevent the organisation of diplomatic embassies. Indeed, the acting Danish consul in Tripoli, the trader Lochner, tried to prevent 'Abd al-Rahmmān Aġa's departure for Copenhagen for over two years. 13

The purpose of the embassy of Tripoli seemed to have been both political and economic. Since the beginning of the reign of the Qaramānlĩ dynasty in 1711, Tripoli's politics had been characterized by increasing autonomy from Istanbul and a strategy of territorial unification, leading to a series of campaigns towards the interior of the country.14 In this context, diplomatic missions to Europe can be seen as part of a political strategy of independence and sovereignty, which started with embassies to Paris in 1719 and London in 1728.15 Dealing directly with European chancelleries was a way to be recognized as a sovereign state independent from Istanbul, even if the legal status of these relations was ambiguous. It was also a way for the Pasha to strengthen his power in an unstable internal political environment. During Ali Pasha's reign the influence of Tripoli's separatist factions had increased so much that it challenged the authority of the Diwan, thereby creating a tense situation. 16 In addition, a series of bad harvests and droughts since 1765 had led to an economic crisis culminating in 1769.17 In this same year Russian Empress Catherine II SENT a fleet in the Mediterranean to open up a second naval front against the Ottomans. The impact on the Regency's trade was disastrous, as Russians considered Tripoli an Ottoman province and did not hesitate to stop French, English, and other neutral ships from trading with them. In his despatch of April 1771, Lochner described this critical situation, with trade and navigation almost completely

13 Rigsarkivet, Copenhagen, 1771-1789 Tripolis depecher 1771, file 1, Letter from Lochner to Bernstorff, August 1771; The National Archives, London, FO-160-3, Letter from Lochner, June 5 th 1770 , folio 46 verso.

14 Kọla Folayan, Tripoli During the Reign of Yusuf Pasha Qaramanli (Ife: University of Ife Press, 1979), 3; Sharfeddine, La Classe Marchande, 69; Budeeb, Zeddan, "Les Relations Diplomatiques Entre la Régence de Tripoli et la France (1711-1832)," (unpublished PhD diss., Université de Provence Aix-Marseille I, 1995), 1-2.

15 Sharfeddine, La Classe Marchande, 179; Seton Dearden, A Nest of Corsairs: The Fighting Karamanlis of the Barbary Coast (London: John Murray Publishers, 1976), 62.

16 Ibid., 82.

17 Laurent-Charles Féraud, Annales Tripolitaines (Saint-Denis: Bouchene, [1927] 2005), 250; Jean-Claude Zeltner, Tripoli, Carrefour de l'Europe et des Pays du Tchad 1500-1795 (Paris: L'Harmattan, 1992), 242-243. 
stoppedand starvation looming. 18That same yearanepidemic decimated the slave caravan from Fezzan and the Awlad Sulayman refused to pay taxes. Furthermore, serious grain shortage was aggravated by the inability to trade with Levantinemarkets. The loss of tax revenuewasseriously depleting the Regency's revenues and as a result Ali Pasha was buried in debt. 19 In this context, renegotiating peace meant potentially gaining access to payments in cash from European Monarchies to the Regency and possibly new trade opportunities, such as selling salt to the Nordic countries.

\section{A Most Enlightened Man}

In the $18 \mathrm{TH}$ century Maghreb, being chosen as an envoy was a mark of distinction, and diplomatic appointment was eagerly sought. Maghrebi states had no permanent embassies abroad. Negotiations were carried out by special envoys appointed by the ruler who travelled to Europe on specific missions and came back as soon as they completed their assignment. However, it seems that in the $17 \mathrm{TH}-18 \mathrm{TH}$ century Maghreb, the ambassadorial function was professionalized. Rulers selected ambassadors who had travelled widely and had become familiar with the societies of the nașārá.20 In Tripoli during the Qaramānlī period most Tripolitan ambassadors worked with European consuls in Tripoli and were sent on missions to Europe on a regular basis.

The Barshaw's ambassador to Europe in 1772 had already travelled to Europe on several occasions. He designated himself as al-Sayyid al-Hāğğ 'Abd alRahmān Aga ambassador (anbāšadūr) to the master (șāhib) of the province (wilāyat) of Denmark and Norway.21 Born in 1720, to an influential and renowned family from Tripoli, he was related to the Šaih al-Bilad of the city.22

18 TNAFO-160-3, Letter from Lochner to Osten, April 13th 1771, folio 49 verso.

19 Anne-Charles Froment de Champlagarde, Histoire Abrégée de Tripoly de Barbarie, ed. Alain Blondy (Saint-Denis: Bouchène, [1794]2001), 27; Marc-Frederick Dyer, The Foreign Trade of Western-Libya 1750-1830 (Unpublished PhD diss., Boston University Graduate School, 1987), 252-253.

20 Matar, In the Lands of the Christians, 95-96.

21 In the Arabic one page travelogue he engraved in Copenhagen, Rigsarkivet, 1770-1777 Tripolis Sager verdr De Tripolitanske gesandtskaber.

22 Anonymous, "44. Unkosten bei der Gesandtschaft von Tripoli nach Schweden, 1780," Briefwechselmeist Historischen und Politischen Inhalts, Siebender Theil, XXXVII-XLII (1780), 237. On his appointment as Sheikh al Bilad I diverge from Nora Lafi's analysis; Nora Lafi, Une Ville du Maghreb entre Ancien Régime et Réformes Ottomanes: Genèse des Institutions Municipales à Tripoli de Barbarie. 1795-191, (Paris: L'Harmattan, 2002), 146. 
Well-trained diplomat, he had already conducted embassies in Istanbul in 1746; in Venice in 1763-64 to negotiate peace; in Florence in 1765 to congratulate the Grand Duke of Tuscany for his accession to the throne; and in Prussia to congratulate the Kaiser for the same reason. 23 He was acting consul of Tuscany in Tripoli at the time he left for Copenhagen.24 Miss Tully who frequented 'Abd al-Rahmān and his family between 1783 and 1790, described him as 'a most enlightened man, having been repeatedly to the chief courts of Europe', who was in Tripoli 'universally beloved by Christians as well as Moors, and adored by his family'.25

Abd al-Rahmān Aga had already twice accomplished the pilgrimage to Mecca, once in 1760 and then again with his family in 1768.26 Like the Pasha, his ministers, the rāyis and most of the high-ranking officials during the Qaramānlī period in Tripoli, he was also an active trader with extensive foreign connections.27 As a merchant, he was involved in the Caravane maritime and rented European ships to carry goods and passengers between ports in Europe, the Ottoman Empire and North Africa.28 From the charter contracts signed by him, copies of which are kept in London and Nantes, we can see that he traded with British, French, Italian and Spanish captains to ship goods to Naples, Marseille, Leghorn, Smyrna, Venice, Malta, Tunis, Bône Benghazi, Alexandria, Istanbul and the Levantine ports.29 He traded a broad range of goods including grain (corn, bran, barley), plants (beans, alizaris/ 'urūq fuwwa, barils or prickly saltwort), cattle, fabrics, furniture and also African slaves. One third of his contracts contain a clause discharging the captain's liability in case of death of the 'negroes,'30 proving he was involved in the slave trade, which explains his relations with traders in the interior of Africa. 31 The diversity of products

23 Buheeb, Les Relations Diplomatiques, 110; Anonymous, "44. Unkosten," 238.

24 TNA, FO-160-3, folio 45 verso, Letterfrom Lochner to Bernstorff, May 26th 1770.

25 Letter from July 24th 1784, Miss Tully, Narrative of a Ten Years' Residence at Tripoli in Africa, from the Original Correspondence in the Possession of the Family of the Late Richard Tully (London: H. Colburn[1816]1817), 55.

26 Tully, Narrative, 189-191.

27 Sharfeddine, La Classe Marchande, 264.

28 Daniel Panzac, La Caravane Maritime: Marins Européens et Marchands Ottomans en Méditerranée, 1680-1830 (Paris: CNRS, 2004), 11.

29 Centre des archives diplomatiques de Nantes (CADN), Tripoli, 706PO-1-2 1757; Tripoli, 706PO-1-4 1768-1777; 706PO-1-71785-1787;706PO-1-81788-1792;FO 160-4.

30 The established formula is: "Le capitaine ne répond, ni du muyé [mouillé], ni du gaté, ni mortalité d'animaux et nègres," Contract dated from May 6th 1790, CADN Tripoli, 706PO1-81788-1792 and also contracts kept in 706PO-1-4 1768-1777, 706PO-1-7 1785-1787.

31 Niebuhr, "Das innere von Afrika," 978. 
and outlets in his trade is consistent with the practice of other great Tripolitan traders of this period, such as Hasanal-Faqin Hasan. 32 Itwould appearthathis diplomaticcareeralsohelpedhimexpandhisbusiness, asheusedhismissions to Europe to load ships and to try to avoid paying taxes.33

As was usual for this kind of mission, the Ambassador was not travelling alone. He had with him a retinue including his nephew Ḥağği Musțafā acting as his secretary, a cookand two blackmen designated sometimes as his valets, sometimes as his slaves, accompanying him on his journeys. 'Abd al-Raḥmān's life was intertwined with the lives of his black servants or slaves. In all his travels as a diplomat or during his private trips, for example in his second pilgrimage to Mecca, or in his daily life in Tripoli, heand his second wife always had with them several African slaves.34 From Miss Tully's narrative this seems to have been a customary practice in Tripoli's high society. 'Abdal-Raḥmān also spoke some Kanuri (the language from Bornu), which he had learned from his nanny as a child and from playing with Kanuri children in Tripoli.35When his first wife died, he decided for several years not to marry again but instead to takea black concubine; he said he thought this would be better for his children. 36 In the archives of his second stay in Copenhagen, there is a list detailing his retinue, in which we see three individuals designated by the term neger (black): the cook Hach Belgcer, Hach Marrub, and Hach Barka. Interestingly all three are indicated as having done the pilgrimage which, in all likelihood, they would have accomplished by accompanying 'Abd al-Rahmān during his second trip which was made with a large party. 'Abd al-Rahman and his family members therefore seem to share their existence with black slaves, and trusted slaves accompanied them everywhere and participated in all of their daily lives.

The archives are almost completely quiet about the two sub-Saharan Africans in Copenhagen in 1772. What we know from them we learn from Carsten Niebuhr. Without naming them he describes two young men - one from Timbuktu, and the second born near the Niger River speaking Afnu/Hausa as his national language.37 Niebuhr describes him as a 'young well-grown Kafr with thick lips and a flat nose', who 'had on each cheek several large scars from stab wounds. He himself and his master assured me that it was used to recognize

32 Sharfeddine, La Classe Marchande, 379.

33 TNA, FO-76/3, folio 242; Rigsarkivet, 1770-1777 Tripolis Sagerverdr De Tripolitanske gesandtskaber, file2, August 20 and 21st reports 1773, signed Cartsen Niebuhr.

34 Letter from September 20th 1787, Tully, Narrative, 152.

35 Niebuhr, "Das Innere von Afrika," 982.

36 Letter from July 24 1784, Tully, Narrative, 56.

37 Niebuhr, "Das innere von Afrika," 987 and 1003; Niebuhr, "Bemerkungen," 433. 
his country. 38 This sentence is a rare illustration of scarification practices in the second half of the 18TH century. Let's now look at the everyday life of 'Abd al-Rahmān Aga and his party during their stay in Copenhagen in the summer 1772.

\section{Everyday Interaction and Communication}

In 18TH-century Copenhagen, as elsewhere in Europe, the reception of Maghreb or foreign diplomats followed a strictly codified protocol. The ambassador was accompanied at all times by an interpreter, his accommodation was arranged by the king, and social events were organised for his entertainment. The visit culminated in the envoy's audience with the king. As was customary in early modern diplomacy, daily activities of the ambassador were recorded by the interpreter in a journal, written in this case for the Danish authorities.39 Andreas Freboe, former consul in Algeria from 1763 to 1771, was appointed to serve as 'Abd al-Raḥmān's interpreter because he was supposed to be fluent in Arabic.

Carsten Niebuhr and 'Abd al-Rahmān's first meeting is described by Niebuhr's son in his biography of his father. According to Barthold Georg Niebuhr, ÆEreboe's Arabic skills were very weak and 'Abd al-Rahmmān rapidly felt the need to speak with other people. As Arabic-speaking people were few in Copenhagen at this time, Niebuhr was called upon to assist. He was eager to helpand 'to have the opportunity to hear and speakArabic, to indulge again in the habit so long laid aside and to make himself acquainted with a region of the Arab world that he had not himself visited.'40 Reading Æreboe's Journal, it is unlikely that ithappened this way. ÆEreboerecords the first visit of Niebuhr to the Ambassador's house on July 5th, two days after his arrival, which implies their encounter must have been programmed ahead.

In Æreboe's Journal, we see eighteen visits by Niebuhr to the ambassador's house listed between July 5th and November 26th 1772 . They usually lasted half a day and most of them involved long, one-on-one discussions. Both Niebuhr and 'Abd al-Rahmān refer afterwards to the other as a friend. Niebuhr in the third volume of his travel account, published posthumously, recalls in a footnote coming to the ambassador's home almost every day and becoming his close

38 Niebuhr, "Das innere von Afrika," 981.

39 Rigsarkivet, 1770-1777 Tripolis Sager verdr De Tripolitanske gesandtskaber. The Journal is written in manuscript old Danish black letter, I am thankful to Dan Andersen for deciphering and translating it for me.

40 Barthold Georg Niebuhr, The Life of Carsten Niebuhr, the OrientalTraveller, 3:1-4, (Edinburgh: T. Clark, 1836), 42. 
friend. 41 Likewise 'Abd al-Rahmān in 1773, advises the Danish authorities to ask 'his friend Mister Niebuhr who speaks perfect Arabic' to translate a letter from the Pasha.42 During their meetings they read and discussed Arabic manuscripts and inscriptions, talked about geography and went together to visit the court painter Pilo and the Kunstkammer, the art collection of the Danish king.43 To entertain 'Abd al-Rahmān, ÆEreboe regularly read and translated for him the Gazettes, and parts of Niebuhr's travelogue Beschreibung von Arabien.44 Niebuhr lent him an edition of an Arabic geographer's text, certainly Ibn al-Wardi's Cosmography written around 1428, that he had brought with him from Arabia. 'Abd al-Rahmān was especially fascinated with his description of Denmark.45 Æreboe also saw the Ambassador write down in a notebook the names of the Ministers and the genealogy of the King of Denmark.46 Niebuhr also gave him a copy of the first volume of his narrative Reisebeschreibung and Abd al-Rahmān told him he was going to order an Arabic translation of it in Tripoli.47

Discussions between Niebuhr and 'Abd al-Rahmān took place in Arabic. Niebuhr had started studying the language in 1758 in Gottingen with the Biblical scholar and specialist in ancient eastern languages Johann David Michaelis, while preparing for his expedition to Arabia. But he was, by his own admission, slow in making progress and it was only during his stay in Cairo at the beginning of his journey that his fluency in Arabic grew dramatically as he was using it every day in the streets. $48 \mathrm{He}$ left for Arabia with a basic knowledge of classical Arabic, and came back with a good command of spoken Arabic. During his years in the Middle East, he conversed in Arabic with his acquaintances. In his narrative he describes the variety of dialects he encountered travelling with

41 Carsten Niebuhr, Carsten Niebuhrs Reisebeschreibung nach Arabien und andern umliegenden Länder (Copenhagen: Nicolaus Möller, 1837), 127-128. I am thankful to Michel-Pierre Detalle for drawing my attention to this footnote.

42 Rigsarkivet, 1771-1789 Tripolis depecher 1771, file 2, Letter from Lochner to Bernstorff, January 8th 1775.

43 Rigsarkivet, 1770-1777 Tripolis Sager verdr De Tripolitanske gesandtskaber, AEreboe's Journal, July 19th, August 3rd, August 11TH, September 8th.

44 Idem., Ereboe's Journal, August 11TH, October 14TH.

45 Themanuscriptis part oft hecollection of Arabic manuscripts acquired by participants of the Arabian Journey, 1761-1767 kept and digitized by the Royal Danish Library, manuscript Harīdat al-'ağ '́ 'ib wa-farìdat al-ġarā' ib, Cod. Arab 93, folios 70r-70v. http://www .kb.dk/manus/ortsam/2009/okt/orientalia/da/object59528/ consulted in January 2017. I am grateful to Jean Charles Ducène for identifying the manuscript.

46 Idem., Areboe's Journal, August 14TH.

47 Æreboe, Journal, November 10.

48 Lawrence J. Baack, Undying Curiosity: Carsten Niebuhr and the Royal Danish Expedition to Arabia(1761-1767) (Stuttgart: Franz SteinerVerlag, 2014), 51-52and 119. 
caravans. In Yemen he noted differences in the language and pronunciation of the mountain dwellers and the Imam's courtiers in Sanaa, as well as in today's Iraq between the inhabitants of the city of Basra and the surrounding 'tribes.'49 In Das Innere von Afrika, Niebuhr recalls the difficulty he had in understanding the dialect of a Sheikh from Lamu (modern Kenya) with whom he had spoken in Bombay in 1763.50

He does not mention any problems in communicating with 'Abd al-Rahmān. Niebuhr had mainly learned Arabic on his own in situ, which helped him develop a sense for dialectal diversity which he shared with Abd al-Rahmān. As we have seen, the latter had completed the pilgrimage twice, which in those days meant long stays in the Arabian Peninsula, which probably accustomed him to the Arabic of this area. However, in a letter to Michaelis written on 30 September 1773, Niebuhr reports that while he communicated easily with the Ambassador who dealt regularly with foreign Arabs, when 'Abd al-Rahmān was talking with his entourage, or when they were talking together, he understood less than half of what was said. 51 Most likely 'Abd al-Rahmān made a special effort to be understood, an attitude he would have developed as a diplomat and a merchant. He had conducted business and negotiations in Istanbul, Venice, Livorno, Marseille and Prussia, with people ranging from friends and family to strangers, such as Ottoman and European court officials or merchants and sea captains in the Mediterranean. Europe was neither strange, nor new, nor marvelous to him. In this he differed from other Maghreb ambassadors travelling for the first time in Europe. $52 \mathrm{He}$ spent several months in Venice and he signed letters written in Italian. The letters may have been also written by his secretary, but he was surely familiar with the language or with the Lingua franca.

Although Niebuhr had an excellent command of spoken Arabic, there is evidence in the archives that he could not read it easily. Asked repeatedly by the Danish authorities to translate letters from the Pasha, he replied that beyond the nomia propria and several insignificant words he could notunderstanda text, insisting on the difference between oraland written Arabic. 53

49 Michel-Pierre Detalle and Renaud Detalle, "Carsten Niebuhr etl'Expédition Danoise: Un Mémorandum Adressé en 1768 à l'Académie des Inscriptions et Belles-lettres," Journal des Savants 2, no. 1 (2011): 303; Baack, Undying curiosity, 196.

50 Niebuhr, "Das Innere von Afrika," 972.

51 Letter from Niebuhr to Johann David Michaelis, Copenhagen September 30 1773. NSuUG, Cod. Ms. Mich. 326, BI 301-2 (i.e. Göttingen). I am thankful to Larry Baack for making me aware of this letter.

52 Miller, Disorienting Encounter, 67.

53 Rigsarkivet, 1770-1777 Tripolis Sager verdr De Tripolitanske gesandtskaber, file 2, German report undated signed by Cartsen Niebuhr, around July 1773. Rigsarkivet, 1771-1789 Tripolis depecher 1773-75, file3, German report, March 31st 1775, signed by Cartsen Niebuhr. 
Niebuhrand 'Abdal-Raḥmānhad more in commonthanonewould be inclined to think. Both had had cross-cultural experiences, and both were accustomed to crossing boundaries of language and religion. Niebuhr had used Arabictocommunicateand connect with people in Bombay, Iran, Aleppoor Sanaa during his five years of travel. 'Abd al-Rahmān too was accustomed to negotiating with European, Ottoman or North African traders based in Africa. Their shared experience of a long stay in Arabia certainly helped them understand each other. An anecdote told by Niebuhr shows us how much they knew about cultural differences and could find ways to act appropriately in a different cultural context.54 During his stay in Copenhagen, 'Abdal-Raḥmān did not stand up to greet high ranking officials coming to visit him in his house. When Niebuhr noticed this, as a friend he felt entitled to tell him that Christians in Europe were gentlemen as much as 'Mohammedans' in Barbary, and that he should behave politely. 'Abd al-Raḥmān argued that in Tripoli it would not be seen as appropriate for a person of high rank and an Ambassador as himself to stand up to receive a Christian. To this Niebuhr answered that birth was equally important in Europe and the men visiting him were of high rank just like him. Niebuhr's point was convincing. 'Abd al-Rahmmān did not want to be seen as impolite, and thereafter he made sure that high-ranking visitors would find him standing already so that he would not have to get up for them, but still would not be considered rude. This solution was made possible by their relationship, or as Niebuhr wrote: 'Since he was assured that I was his friend, he did not take offence with this discussion.'

\section{A Scholarly Encounter}

The scholarly conversation between 'Abd al-Rahmān and Niebuhr started on July 19th, when on his third visit to the North African diplomat Niebuhr brought with him Arabic books, manuscripts and copies of inscriptions that he had done in Arabia. They read the inscriptions together and 'Abd al-Rahmān identified quotations from the Qurān. 55 On August 3rd, Niebuhr arrived again with Arabic documents and drawings done in Medina and Mecca about which they discussed at length. 56 The same day they talked about Tripoli and its surroundings. Freboe's journal does not mention a discussion about Africa, or a discussion between 'Abd al-Rahmān, Niebuhr, and the 'Africans.' What we

\footnotetext{
54 Niebuhr, Carsten Niebuhrs Reisebeschreibung, footnote, page 127-128.

55 Idem., Areboe's Journal, July 19th.

56 Idem., Ereboe's Journal, August 3.
} 
know about the making of Das Innere von Afrika comes from Niebuhr's writings and from a draft of this work, in which he regularly mentions his sources of information.

In the introduction to a draft of Das Innere von Afrika retained in Niebuhr's personal archives in Kiel, Niebuhr describes what appears as his project and his philosophy towards informants and second-hand information. $57 \mathrm{He}$ argues that as Europeans would not be able to visit all parts of Africa in the near future, they should try to learn about the region from the traders coming to Cairo or from slaves in the European or American colonies, especially as some of these slaves were literate in Arabic and were 'mollahs' or traders in their native countries, and therefore good informants. People should, he said, 'make the effort to win their friendship and to let themselves be informed by them.' Not every African is competent and willing to do so, he insists, but people should constantly question those they trust and soon they will find valuable informants. This is consistent with his fieldwork methodology in Arabia and his scientific writing practices. During his journey, Niebuhr was an indefatigable and natural conversationalist. $58 \mathrm{He}$ preferred to work without an interpreter, and constantly interrogatedall kinds of people about various subjects, from everyday life, to local names, plants, religions, political structures, or vocabularies. He verified his information with local inhabitants, regularly acknowledging his debt towards his informants.59 In the published version of Das Innere von Afrika, we see the same concern to identify sources. Niebuhr quotes 'Abd al-Rahmān as his source nine times, four times the Afnu/ Hausa slave and once the Timbuktu slave. Moreover, in this text's manuscript he includes two additional references - one to 'Abd al-Rahmān andanother one to both Africans. 60

Both the published textand the manuscript start with the NigerRiver. The discussion about the interior of Africa seems to have started around what was going to become in the next decades a major geographical question: the

57 Folio noted 1, Preliminary version Noch etwas über die mohammedanischen Freistaaten in der Barbarei, Christian-Albrechts-Universität zu Kiel. Universitätsbibliothek, Vorarbeiten zum 3. Band der Reisebeschreibung; 2, http://dibiki.ub.uni-kiel.de/viewer/resolver?u rn=urn:nbn:de:gbv:8:2-1668126 consulted in november 2016. Despite his title the drafted manuscript concerns simultaneously the articles about Maghreb namely Überdie mohammedanischen Freistaaten in der Barbarei and the ones about Africa such as Das Innere von Afrika.

58 Baack, Undying Curiosity, 305.

59 lbid., 374.

60 Folio noted 21, Preliminary version Noch Etwas Über die Mohammedanischen Freistaaten in der Barbarei. 
determination of the source of the Niger, its direction of flow, its course and its end. But what comes next does not seem to be specifically set by European knowledge or questions: patriotism of Africans, 'Afnu' and 'Bernu' kingdoms, religious practices in this area, scarification, languages, war and military tactics, slavery, flora, fauna, system of production, lists and descriptions of places. If we look closely at the structure of the part of Das Innere von Afrika dedicated to central west Africa we see that it is shaped around 'Abd al-Rahmān's knowledge. For example the list of cities in the second half of the text is taken from 'Abd al-Rahmān's account, even though other sources are invoked to enlighten, enhance or question his statements. Niebuhr's interest in Africa grew as a direct consequence of his meeting with 'Abd al-Rahmān and the discussions they had.61 In his 1803 paper, in which he compares Horneman's book with the information he had collected from Abd al-Rahmann, Niebuhr describes a part of his work with the former. He insists on the fact that he recalls Abd al-Rahmān saying Afnu and not Asnu, and he remembers asking him to write down the name in Arabic script to check the spelling.62 In the preliminary version all place-names are written in Arabic showing, that he did so systematically.

By comparing Niebuhr's use of sources in the draft manuscript with the published version, it is possible to identify patterns revealing his hierarchy of authorities. In the draft he mentions that the Timbuktu slave had spoken about a country named Flata with white inhabitants, but the Ambassador believed that these Flata weren't the same as the ones he previously mentioned. 63 In the published version Niebuhr follows 'Abd al-Rahmān's opinion, listing two different 'Flata,' one in the Ambassador's list of cities and one connected to the information given by the Timbuktu slave, carefully adding that the slave couldn't say anything noteworthy except that they were white because he had been abducted when he was too young.64 The statement of the slave was thus cross-checked by interrogating the Ambassador to whom was given more credit. One reference to the fact that the information had been given by the 'Africans' disappeared in the published version, where the information is still quoted but without attribution.65 However, on several matters, the knowledge of the slave from Afnu/Hausa was specifically sought, as with regards to the

61 This is confirmed by hisson, Barthold Georg Niebuhr, The Life of Carsten Niebuhr, 43.

62 Niebuhr, "Bemerkungen," 432.

63 Folio noted 29, Preliminary version Noch Etwas Über die Mohammedanischen Freistaaten in derBarbarei.

64 Niebuhr, "Das innere von Afrika," 988 and 990.

65 Folio noted 21, Preliminary version Noch Etwas Über die Mohammedanischen Freistaaten in der Barbarei; Niebuhr, "Das Innere von Afrika," 986. 
various names of the Niger River, the Afnu/Hausa language or on the use of cowries. Niebuhr's hierarchy of trustworthiness thus seems to place direct observation by an established European scientist on top; information acquired from a literate or experienced adult male first-hand observer (Tripolitan or Hausa) in the middle; and information provided by an African enslaved at a young age at the bottom. More than social or racial hierarchy, what discredited the Timbuktu slave'sinformation to Niebuhr's eyes, was his youngage when he was abducted and forced to leave the region.

'Abd al-Rahmān appears to have considered his slaves (and especially his Afnu/Hausa slave) as potentially valuable informants. Accordingly, heencouraged Niebuhr to question them. He also made a careful distinction between what he had witnessed himself, and what he had been told, which certainly further enhanced his credibility for Niebuhr. 'Abd al-Rahmān's knowledge about the interior of Africa derived, as stated by Niebuhr, from his interactions as a trader with North Africans based in the interior of Africa. In the preliminary version there is a longer description of them: 'some traders of [Tripoli] spent several years there and came back rich. Others never came back because they found the country better than theirs and because justice is better served there than in white "Mohammedan" countries.'66 Niebuhrnever says anything about the goods that 'Abd al-Rahmān and those traders exchanged, but they were most likely slaves. Regarding 'Abd al-Raḥmān's credibility, Niebuhr notes twice that his description of things could have been influenced by his fidelity tohis Pasha. This raises the issue of the projects behind the texts.

\section{$5 \quad$ Intellectual Agendas and Writing Genres}

To try and grasp the projects and cultural viewpoints embodied in this text we need, as Moraes Farias taught us, to think about Niebuhr's text on Africa as a wholeand nota collection of parts. Weneed to understand how this text was constructed and how it integrated both Niebuhr's and 'Abd al-Rahmān's visions and aims. 67 Only by looking at the five texts and their drafts does it become possible to identify the political and intellectual agendas that nourish them.

From the draft, it seems that Niebuhr had a project to write a piece on all the information he had collected from various sources about Africa, including

66 Folio noted 21, Preliminary version Noch Etwas Über die Mohammedanischen Freistaaten in derBarbarei.

67 Moraes Farias, Arabic, XLVII. 
what he had learned about the west coast of the Arabian Gulf, about Habbesch and the surroundings area, about the Arabs of the south east coast of Africa and the lands of the blacks.68 The various pieces were at some point scattered and published in distinct articles and chapters. In the preliminary version and in the various published papers we see two main arguments - the validity of second hand information in regions that have not been visited by Europeans and the opportunity to explore Africa with the right method. Niebuhr's approach towards scientific travel was that travellers should speak the local language, and learn about the culture and customs of the place they are visiting. For Niebuhr the planning of an exploration mission required the preliminary gathering of second-hand information, to develop a travel plan and gain at least some familiarity with the languages, religions, and topography of the areas to be visited.69 Das Innere von Afrika can be seen as a collection of information intended to assist future European travellers developing projects for expeditions.70 'Abd al-Rahmān, understood this agenda and even supported the idea of a scientific exploration of Tripoli. In his speech at the Swedish Academy of Science in 1773, he offered to support and help fund a European exploration of the Regency. Indeed when he returned to Tripoli from Sweden he brought with him the naturalist Göran Rothman and helped him during his travels, as he did later with Simon Lucas.71

To understand what Abd al-Rahmān had in mind when he worked with Niebuhr, we need to consider the social and intellectual context of Tripoli. During the Qaramānlī period the country witnessed an intellectual growth, characterized by the intellectual leadership of an Arabicised, local and independent literate elite.72 The Pasha lavished attentions on the 'ulama' (learned men), promoted the resumption of the rihla (travel narrative) and the number of zāwiyas increased. Ahmad al-Qaramānlī, the founder of the dynasty, sponsored the work of Muḥammad b. Halīl Ibn Ġalbūn (dead in 1763-1764?), a

68 Folio noted 1, Preliminary version Noch Etwas Über die Mohammedanischen Freistaaten in der Barbarei.

69 This argument is better expressed in Niebuhr, "Bemerkungen," 429-430.

70 Weknow that at some point Niebuhr thought he could be this traveller, Barthold Georg Niebuhr, The Life of Carsten Niebuhr, 43.

71 ASwedish translation of his speech by Baage is kept in the archives of the Royal Academy of Science in Stockholm, Sekreterarens arkivk. 10:3. ADutch version was published in De Maandelykse Nederlandische Mercurius, March 1773, 90-91. I am thankful to Rafaël Thiebaut for his translation. Concerning 'Abd al-Raḥmān regarding's role in Lucas's journey, see TNA, FO-76/05, letter 162.

72 Ammar Guhaydar, "Sources Pour l'Étude de la Vie Intellectuelle en Libye à l'Époque des Karamanli," Revue d'Histoire Maghrébine 59-60 (October 1990): 165. 
chronicler commissioned to write the story of Tripoli.73 His book was the first attempt to present the history of the Regency in a unified narrative. Indeed, the description of the history and geography of Tripoli provided by 'Abd alRahmān to Niebuhr seems to have been influenced by the emergence of a scholarly discourse that emphasised political autonomy and intellectual pride. Abd al-Rahmān insists on the dynastic and hereditary nature of the power of the Qaramānlī, describes a regency controlling Fezzan and Cyrenaica and a Pasha with absolute powers comparable to the Ottoman Sultan.74 'Abd al-Rahmān's description of the advent of the Qaramānlī dynasty and of Ahmad Qaramānli's takeover is clearly derived from the official history of the Qaramānlī, as written by Ibn Galbūn who was an eye witness of its establishment.75 Niebuhr is not wrong in considering this part of 'Abd al-Rahmān report as influenced by the latter's proximity to the Pasha. Proud diplomat, his discourse can be seen as shaped by a desire to glorify the Qaramānli dynasty and the Regency of Tripoli.

The issue of national pride is also raised when discussing 'Africans.' Niebuhr wrote in one of his classical attempts to correct European prejudice, that while European scholars were still uncertain whether Africans were men or monkeys, these Africans considered themselves to be the finest and most important of all nations.76 Miss Tully in her narrative also recalled that the Prince of Fezzan who came to Tripoli at the end of 1788 , considered his country as the 'most fertile and beautiful in the world.'77

The Maghreb tradition of the rihla was definitely part of 'Abd al-Rahmān's cultural repertoire, as formost of his Maghreb learned contemporaries, providing the logical form in which to cast travel experiences. 78 We do not know if 'Abd al-Raḥmān wrote a rihlla hijāzìya of his two pilgrimages, but he did deliver a long oral narrative of his second pilgrimage to Miss Tully.79 Regarding what he thought about his travels to Europe, we only havea one-page travelogue he wrote and had printed in Copenhagen, thanks to Niebuhr's help.80 The text has a formal tone and follows the rhetorical conventions of Arabic diplomatic writing. It starts with a preamble about the Ambassador's ruler and his lineage,

\footnotetext{
73 Ibid.

74 Niebuhr, "Noch Etwas Über die Mohammedanischen Freistaaten in der Barbarei. Fortsetzung," 119-120; Niebuhr, "Das Innere von Afrika," 994.

75 Ibn Ghalbun, al-Tidhkār fiman malaka Tarāblus; quoted in Féraud, Annales Tripolitaines, 204-205.

76 Niebuhr, "Das innere von Afrika," 979-980.

77 Tully, Narrative, 183.

78 Miller, Disorienting Encounter, 52.

79 Tully, Narrative, 191-194 and 199-200.

80 Rigsarkivet, 1770-1777Tripolis SagerverdrDe Tripolitanske gesandtskaber.
} 
followed by a praise of his host, the Danish King, and his lineage. The Ambassadorwascarefulabouttheaccuracy of thedetailsheprovides: hetransliterated the names and the titles, and collected the genealogy of the Danish kings. 81 In this preamble, honorific titles and genealogy are mentioned to project a positive image of the European potentate reflecting back on the authority of the Ambassador and his ruler. The second part of the text describes how the Ambassador was received in Copenhagen. It is designed to impress the elite in Tripoli, insisting on the royal carriage reserved for the Ambassador, the horses for his retinue, the crowd who came to praise him and the joy of the King when hemettheAmbassador, allof itmaking ita 'greatday in scaleand importance.'82 'Abd al-Rahmān brought sixty printed copies of this text back toTripoli, at a time when printing was rarely used in the OttomanEmpireand Maghreb. This text was widely circulated, discussed and admired within the court in Tripoli.83

Ahead of his time, and fifteen years before the creation of the African Association, Niebuhr's text represented Africa as an object of geographical and scientific interest. But his project of exploration of central west Africa went unheeded for years and his work on Africa remained almost unknown for centuries. By studying how he composed his texts, we can reconstruct the process through which oral and written information became intertwined and shaped his ideas; and we can reveal his perceived hierarchy of sources. These texts are the result of information circulating broadly across linguistic, geographic and cultural boundaries. This information had been gathered through the rich cross-cultural experiences of Niebuhr, 'Abd al-Rahmān and the two slaves. Das Innere von Africa can be summed up as a Tripolitan notable's observations on the interior of Africa, crosschecked against the testimonies of two African servants or slaves, and analyzed and put into narrative form by a German explorer and specialist of Arabia. It sheds light not only on the discourses of Tripolitan traders about the Central Sahara and Sahel butalso on the answers of two subSaharan African slaves asked to provide information about their homeland. It is an example of co-produced knowledge across cultures, languages, and status groups, a complex text that reveals-most of all-an ongoing intellectual dialogue and collaboration between African and European authors.

81 Which is not unusual; Matar, In the Lands of the Christians, 95.

82 'Abd al-Rahmmān's text kept in Rigsarkivet, 1770-1777 Tripolis Sager verdr DeTripolitanske gesandtskaber. I am thankful to Robin Seignobos and Ismail Warsheid for helping me with the translation of the Arabic text.

83 Rigsarkivet, 1771-1789 Tripolis depecher 1771 file 2, letter from Lochner to Bernstorff, January 81775 . 


\section{References}

\section{Archival Sources}

Centre des archives diplomatiques de Nantes (CADN)b, Tripoli, Affaires commerciales et diverses correspondances 706PO-1-2 1757; Tripoli, 706PO-1-4 1768-1777; 706P0-1-7 1785-1787; 706PO-1-8 1788-1792.

Christian-Albrechts-Universitätzu Kiel. Universitätsbibliothek, Niebuhrs Personal Archives Vorarbeiten zum 3. Band der Reisebeschreibung; 2, Preliminary version of Noch etwas über die mohammedanischen Freistaaten in der Barbarei, http://dibiki .ub.uni-kiel.de/viewer/resolver?urn=urn:nbn:de:gbv:8:2-1668126.

Rigsarkivet-Copenhagen, 302 Dept for de Udenlandske Anligg/Foreign Affairs, 17711788 Tripolis: Breve fra deyen af Tripolis; 1770-1777 Tripolis: Sager verdr. De Tripolitanske gesantskaber; 1771-1789 Tripolis depecher.

The National Archives, London (TNA), Foreign Office 160-4, 160-3, 160-32, 76-4.

\section{Published Sources}

Anonymous, "44. Unkosten bei der Gesandtschaft von Tripoli nach Schweden, 1780." Briefwechsel meist historischen und politischen Inhalts, Siebender Theil, XXXVIIXLII, (1780): 235-238.

Aslanian, Sebouh David. From the Indian Ocean to the Mediterranean: The Global Trade Networks of Armenian Merchants from New Julfa. Berkeley: University of California Press, 2011.

Baack Lawrence, J. Undying Curiosity: Carsten Niebuhr and the Royal Danish Expedition to Arabia (1761-1767). Stuttgart: Franz Steiner Verlag, 2014.

Budeeb, Zeddan. Les Relations Diplomatiques entre la Régence de Tripoli et la France (1711-1832). Unpublished PhD dissertation, Université de Provence Aix-Marseille I, 1995.

Calafat, Guillaume. "Ottoman North Africa and ius publicum europæeum: The Case of the Treaties of Peace and Trade (1600-1750)." In Antonella Alimento, ed., War, Trade and Neutrality: Europe and the Mediterranean in the Seventeenth and Eighteenth centuries (Milan: Angeli, 2011), 171-187.

Dearden, Seton. A Nest of Corsairs: The Fighting Karamanlis of the Barbary Coast. London: John Murray Publishers, 1976.

Detalle, Michel-Pierre, and Renaud Detalle. "Carsten Niebuhr et l'Expédition Danoise en Arabia Felix: Un Mémorandum Adressé en 1768 à l'Académie des Inscriptions et Belles-lettres." Journal des Savants 2, no. 1 (2011): 277-332.

Dyer, Marc-Frederick. The Foreign Trade of Western-Libya 1750-1830. Unpublished PhD dissertation, Boston University Graduate School, 1987.

Féraud, Laurent-Charles. Annales Tripolitaines. Saint-Denis: Bouchene, [1927] 2005. 
Fọlayan, Kọla. Tripoli During the Reign of Yusuf Pasha Qaramanli. Ife: University of Ife Press, 1979.

Froment de Champlagarde, Anne-Charles. Histoire Abrégée de Tripoly de Barbarie, edited by Alain Blondy. Saint-Denis: Bouchène, [1794] 2001.

García-Arenal, Mercedes, and Gerard Wiegers. A Man of Three Worlds: Samuel Pallache, a Moroccan Jew in Catholic and Protestant Europe. Baltimore: Johns Hopkins University Press, 2003.

Ghobrial, John-Paul, "The Secret Life of Elias of Babylon and the Uses of Global Microhistory." Past and Present 222 (2014): 51-93.

Ghobrial, John-Paul A. The Whispers of Cities: Information Flows in Istanbul, London, and Paris in the Age of William Trumbull. Oxford: Oxford University Press, 2013.

Grenet, Mathieu. "Muslim Missions to Early Modern France C.1610-c.1780: Notes for a Social History of Cross-Cultural Diplomacy." Journal of Early Modern History 19 (2015): 1-22.

Guhaydar, Ammar. "Sources Pour l'Étude de la Vie Intellectuelle en Libye à l'Époque des Karamanli." Revue d'Histoire Maghrébine 59-60 (October 1990): 165-172.

Ibn Ghalbun, Muḥammad b. Khalīl. al-Tidhkār fimman malaka Tarāblus wa mā kāna bihā mina al-akhyār. Edited by al-Țāhir al-Zāwī. Beirut, 2004.

Lafi, Nora. Une Ville du Maghreb Entre Ancien Régime et Réformes Ottomanes: Genèse des Institutions Municipales à Tripoli de Barbarie, 1795-1911. Paris: L'Harmattan, 2002.

Matar, Nabil. In the Lands of the Christians: Arabic Travel Writing in the Seventeenth Century. London: Routledge, 2003.

Miller, Susan Gilson. Disorienting Encounters: Travels of a Moroccan Scholar in France in 1845-1846: The Voyage of Muhammad as-Saffār. Los Angeles: University of California Press, 1992.

Moraes Farias, Paulo Fernando de. Arabic Medieval Inscriptions from the Republic of Mali: Epigraphy, Chronicles, and Songhay-Tuāreg History. Oxford: Oxford University Press, 2003.

Moraes Farias, Paulo Fernando de. "Barth, Fondateur d'une Lecture Réductrice des Chroniques de Tombouctou." In Mamadou Diawara, Paulo Fernando de Moraes Farias, and Gerd Spittler, eds., Heinrich Barth et l'Afrique (Cologne: R. Köppe, 2006), 215-224.

Niebuhr, Barthold Georg. The Life of Carsten Niebuhr, the Oriental Traveller. Edinburgh: T. Clark, 1836.

Niebuhr, Carsten. Carsten Niebuhrs Reisebeschreibung nach Arabien und andern umliegenden Länder 3. Copenhagen: Nicolaus Möller, 1837.

Niebuhr, Carsten. "Das Innere von Afrika." Neue Deutsches Museum (October 1790): 963-1003.

Niebuhr, Carsten. "Noch Etwas Über das Innere von Afrika." Neues Deutsches Museum (May 1791A): 419-435. 
Niebuhr, Carsten. "Noch Etwas Über die Mohammedanischen Freistaaten in der Barbarei." Neues Deutsches Museum (January 1791B): 1-26.

Niebuhr, Carsten. "Noch Etwas Über die Mohammedanischen Freistaaten in der Barbarei. Fortsetzung." Neues Deutsches Museum (February 1791c): 115-133.

Niebuhr, Carsten. "Bemerkungen Über Fr Hornemann's Reise nach denn Innern von Afrika." Monatlische Correspondenz (1803): 429-435.

Panzac, Daniel. "Une Activité en Trompe-l'œil: La Guerre de Course à Tripoli de Barbarie dans la Seconde Moitié du XVIII Siècle." Revue de l'Occident Musulman et de la Méditerranée 47 (1988).

Panzac, Daniel. La Caravane Maritime: Marins Européens et Marchands Ottomans en Méditerranée, 1680-1830. Paris: CNRS, 2004.

Rothman, E. Natalie. Brokering Empire: Trans-Imperial Subjects between Venice and Istanbul. Ithaca: Cornell University Press, 2012.

Sharfeddine, Enaam. La Classe Marchande dans l'Iyalat Ottoman de Tarabulus al-Gharb (Tripoli) sous les Qaramanlis 1711-1835. Unpublished PhD dissertation, Aix-Marseille Université, 2012.

Trivellato, Francesca. The Familiarity of Strangers: The Sephardic Diaspora, Livorno, and Cross-Cultural Trade in the Early Modern Period. New Haven: Yale University Press, 2009.

Tully, Miss. Narrative of a Ten Years' Residence at Tripoli in Africa, from the Original Correspondence in the Possession of the Family of the Late Richard Tully. London: H. Colburn [1816] 1817.

Valensi, Lucette. Ces Étrangers Familiers: Musulmans en Europe, XVIe-XVIIIe siècles. Paris: Éd. Payot \& Rivages, 2012.

Windler, Christian. La Diplomatie Comme Expérience de l'Autre: Consuls Français au Maghreb (1700-1840). Genève: Groz, 2002.

Windler, Christian. "Diplomatic History as a Field for Cultural Analysis: MuslimChristian Relations in Tunis, 1700-1840." The Historical Journal 44, no. 1 (2001): 79-106.

Zeltner, Jean-Claude. Tripoli, Carrefour de l'Europe et des Pays du Tchad 1500-1795. Paris: L'Harmattan, 1992. 